\title{
Psychiatric Symptoms of Patients with Epilepsy
}

\section{Epilepsi Hastalarında Psikiatrik Semptomlar}

\author{
Yasemin ÜNAL, ${ }^{1} \odot$ Leman INANÇ, ${ }^{2} \odot$ Ümit Başar SEMIZ, ${ }^{2} \odot$ Gülnihal KUTLU1
}

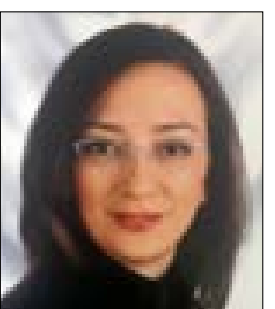

Dr. Yasemin ÜNAL

\author{
'Department of Neurology, Muğla Sıtkı Koçman University Faculty of Medicine, Muğla, Turkey \\ 2Department of Psychiatry, Muğla Sıtkı Koçman University Faculty of Medicine, Muğla, Turkey
}

\section{Summary}

Objectives: Psychiatric symptoms such as anxiety, depressive symptoms, psychotic symptoms, and mental retardation are much more common among patients with epilepsy (PWE) than the general population. This study aimed to evaluate psychiatric symptoms in patients with epilepsy.

Methods: Symptom Checklist 90-R Revised (SCL-90-R) was given to all consecutive patients with epilepsy in outpatient Epilepsy Department. Participants completed the SCL-90-R questionnaire. One neurologist and one psychiatrist evaluated these forms. Subscales of somatization, obsessive-compulsive thoughts, interpersonal sensitivity, depression, anxiety, phobic anxiety, psychoticism, paranoid ideation, and hostility were evaluated.

Results: A total of 111 PWE and 92 sex- and age- matched control subjects were included. The mean age of the patient group was $34.05 \pm 10.90$ years. Of the patients, 43 were male and 68 were female. Fourteen (12.61\%) patients were diagnosed with mental retardation. Based on our results of mean SCL-90-R score for each item, somatization, obsessive-compulsive symptoms, interpersonal sensitivity, depression, anxiety, hostility, phobic anxiety, paranoid ideation, and psychoticism were significantly higher in the patient group than the control subjects.

Conclusion: SCL-90-R is an easy test to evaluate psychiatric symptoms. It can be used for PWE to raise awareness of psychiatric symptoms. Once the clinicians become more aware of such symptoms, more accurate approach to the patients will be possible. In terms of follow-up of PWE, not only seizure frequency and severity but also other psychiatric symptoms are important.

Keywords: Epilepsy; psychiatric symptoms; SCL-90-R; seizure.

\section{Özet}

Amaç: Epilepsi hastalarında anksiyete, depresif belirtiler, psikotik belirtiler ve mental retardasyon gibi psikiyatrik belirtiler genel populasyona göre daha yaygindir. Bu çalışmanın amacı epilepsi hastalarında psikiyatrik belirtileri değerlendirmektir.

Gereç ve Yöntem: Katılımcılara SCL-90-R psikolojik belirti tarama testi uygulandı. Epilepsi polikliniğinde takip edilen epilepsi hastaları ardışık olarak dâhil edildi. Formlar bir psikiyatri ve bir nöroloji uzmanı tarafından değerlendirildi. Somatizasyon, obsesif-kompulsif düşünceler, kişiler arası duyarlıık, depresyon, anksiyete, fobik anksiyete, psikotizm, paranoid düşünce ve düşmanlık alt ölçekleri değerlendirildi.

Bulgular: Yüz on bir epilepsi hastası ile cinsiyet ve yaş uyumlu 92 kontrol olgu çalışmaya dâhil edildi. Epilepsi hastalarının yaş ortalaması $34.05 \pm 10.90$ yıl idi. Hastaların 43'ü erkek, 68'i kadındı. On dört hasta (\%12.61) mental retardasyon tanısı aldı. Her madde için ortalama SCL-90-R skoru sonuçlarına dayanarak yapılan değerlendirmede somatizasyon, obsesif kompulsif belirtiler, kişiler arası duyarlıık, depresyon, anksiyete, düşmanlık, fobik anksiyete, paronoid düşünce ve psikotizm semptomları hasta grupta kontrollere göre anlamlı derecede yüksekti.

Sonuç: SCL-90-R psikolojik belirti tarama testi psikiyatrik semptomların taranmasında kullanılabilecek kolay bir testtir. Epilepsi hastalarında psikiyatrik semptomlarla ilgili farkındalığı artırmak için kullanılabilir. Klinisyenlerin bu belirtilere farkındalığı arttığında hastalara daha doğru bir yaklaşım mümkün olacaktır. Epilepsi hastalarının izlenmesi açısından sadece nöbet sıklığı ve şiddeti değil aynı zamanda diğer psikiyatrik belirtiler de önemlidir.

Anahtar sözcükler: Epilepsi; psikiatrik semptom; SCL-90-R; nöbet.

Submitted (Geliş): 22.05.2019

Accepted (Kabul) : 11.06.2019

Correspondence (illetişim): Yasemin ÜNAL, M.D. e-mail (e-posta): yaseminunal95@yahoo.com 


\section{Introduction}

Patients with epilepsy (PWE) may have many comorbid conditions that are classified into neurological, psychiatric, and systemic conditions. Comorbid conditions such as migraine and psychiatric disorder share the similar pathophysiological mechanism with epilepsy, whereas some of them, such as stroke, intracerebral tumors, have cause-result relationship. ${ }^{[1]}$ Approximately $50 \%$ of PWE have various psychiatric disorders like mood, anxiety, and psychotic disorders. ${ }^{[2,3]}$ PWE usually have higher prevalence of psychiatric illness than the general population. ${ }^{[4]}$ The relationship between such disorders and epilepsy is usually complex, and epilepsy itself cannot explain the above-mentioned high rates of prevalence. Hippocrates had suggested epilepsy might be a risk factor for depression; and depression, as well, may be a risk factor for epilepsy. ${ }^{[3]}$ In other words, he defined a bidirectional relationship between them. ${ }^{[5]}$ The incidence of cognitive and psychiatric problems is also high in newly diagnosed epilepsy. It is likely that seizures and neurobehavioral problems represent different symptoms of similar etiologies and a wide network of disorders. However, the likelihood of a psychiatric disorder is usually neglected in PWE.

\section{Clinical rationale for the study}

This study aimed to draw attention to the psychiatric symptoms of PWE by using a simple questionnaire and identify patients who would require referral for clinical evaluation.

\section{Materials and Methods}

Patients who were followed up at outpatient Epilepsy Department were included sequentially between April and June 2017. Age, sex, detailed medical history, type of seizure and epilepsy, seizure frequency, duration of epilepsy, used antiepileptic drugs, as well as electroencephalography (EEG) and neuroimaging findings were recorded for each patient. The patients who had nonepileptic events were excluded from the study.

The Symptom Checklist 90 (SCL-90) is a self-report scale developed by Derogatis that was designed to measure the psychiatric symptoms and psychological distress in psychiatric and medical patients. ${ }^{[6]}$ Each item of this scale has the following five response categories: $0=$ not at all, $1=$ little, 2 = some, 3 = very, 4 = severe. The SCL-90-R subscales assess nine psychiatric symptoms: somatization, obsessive-compulsive, interpersonal sensitivity, depression, anxiety, hos- tility, phobic anxiety, paranoid ideation, and psychoticism. Seven additional questions primarily measure symptoms about appetite and sleep patterns, and are not scored collectively as a dimension. The Global severity index (GSI) is the average score for all responded items and shows an overall distress caused by psychiatric symptoms. For this scale, 1 is usually accepted as a cutoff value, but cutoffs for SCL-90-R changes may be calculated from an average score for a specific sample. Dag ${ }^{[7]}$ and Kilic ${ }^{[8]}$ translated and adapted SCL-90-R Turkish. The test-retest reliability coefficients range between 0.75 and 0.87 for the subscales. The SCL-90-R tests were given to all PWE in outpatient Epilepsy Department sequentially. Age- and sex-matched 92 control subjects also performed this test. One neurologist and one psychiatrist evaluated these forms. Psychopathology levels were detected based on the obtained scores for the subscales of somatization, obsessive-compulsive, interpersonal sensitivity, depression, anxiety, phobic anxiety, psychoticism, paranoid ideation, and hostility.

Informed consent form for the study were obtained from all PWE and control subjects. The local ethics committee has approved this study.

Statistical analysis was carried out using IBM Statistical Package for Social Sciences (IBM SPSS Version 20.0 for Mac OS; SPSS, USA). Independent-sample t tests and chi-square test were used statistically, and $p$ values $<0.05$ were accepted as significant.

\section{Results}

A total of 111 PWE who were followed up at our outpatient Epilepsy Department were included in this study sequentially. The mean age of the patient group was $34.05 \pm 10.90$ years (age range: 18-64 years). There were 43 (38.7\%) males and 68 (61.26\%) females. Fourteen (12.61\%) patients had mental retardation; seven of them had mild, three had moderate, and four had severe mental retardation. A total of 79 (71.2\%) PWE had focal onset seizures, while 31 had generalized seizures. Only one patient had unclassified seizures. Forty-nine (44.14\%) PWE had drug-resistant epilepsy ${ }^{[9]}$ Antiepileptic drugs used by PWE are shown in Table 1.

Patients who had mental retardation were not able to fillin the SCL-90-R. Eventually, 97 patients and 92 controlled subjects completed SCL-90-R. The mean age of the patient group who performed the test was $34.76 \pm 10.77$ years (age 
Table 1. Antiepileptic drugs used by patients with epilepsy

\begin{tabular}{lcc}
\hline \multirow{2}{*}{ Drug } & \multicolumn{2}{c}{ Patients } \\
\cline { 2 - 3 } & $\mathrm{n}$ & $\%$ \\
\hline Carbamazepine & 49 & 45.0 \\
Oxcarbazepine & 8 & 7.3 \\
Lamotrigine & 25 & 22.9 \\
Valproic acid & 55 & 50.5 \\
Levetiracetam & 46 & 42.2 \\
Pregabalin & 3 & 2.8 \\
\hline
\end{tabular}

Table 2. Scores of SCL-90-R for each item

\begin{tabular}{lccc}
\hline Item & PWE & Control & $\mathrm{p}$ \\
\hline Somatization & $1.08 \pm 0.80$ & $0.77 \pm 0.72$ & $<0.05$ \\
OCD & $1.45 \pm 0.85$ & $1.02 \pm 0.74$ & $<0.001$ \\
IS & $1.24 \pm 0.99$ & $0.79 \pm 0.67$ & $<0.001$ \\
Depression & $1.24 \pm 0.90$ & $0.80 \pm 0.64$ & $<0.001$ \\
Anxiety & $1.12 \pm 0.87$ & $0.55 \pm 0.52$ & $<0.001$ \\
Hostility & $1.19 \pm 1.06$ & $0.64 \pm 0.69$ & $<0.001$ \\
Phobic anxiety & $0.87 \pm 0.85$ & $0.31 \pm 0.45$ & $<0.001$ \\
Paranoid & $1.20 \pm 0.93$ & $0.81 \pm 0.66$ & $<0.001$ \\
Psychoticism & $0.75 \pm 0.74$ & $0.42 \pm 0.53$ & $<0.001$ \\
GSI & $1.13 \pm 0.78$ & $0.70 \pm 0.54$ & $<0.001$ \\
\hline
\end{tabular}

PWE: Patients with epilepsy; OCD: Obsessive-compulsive disorder; IS: Interpersonal sensitivity; GSI: General Severity Index.

range: 18-64 years), while the mean age of the healthy subjects was $37.76 \pm 10.94$ years. Sixty-one (62.9\%) of the respondent patients were female, while the remaining were male. There were no differences by age or sex between PWE and control subjects ( $p>0.05$ ).

Of 97 PWE, somatization was detected in 43 (44.3\%); anxiety in 45 (46.4\%); obsession in 69 (71.1\%); depression in 53 (54.6\%); interpersonal sensitivity in 51 (52.6\%); psychotic symptoms in 31 (32.0\%); paranoid symptoms in 53 (54.6\%); hostility in 45 (46.4\%); and phobic anxiety in $36(37.1 \%)$, as evaluated with the SCL-90-R Checklist.

Based on our results of mean SCL-90-R scores for each item, somatization $(p<0.05)$, obsessive-compulsive symptoms $(p<0.001)$, interpersonal sensitivity $(p<0.001)$, depression $(p<0.001)$, anxiety $(p<0.001)$, hostility $(p<0.001)$, phobic anxiety $(p<0.001)$, paranoid ideation $(p<0.001)$, and psychoticism $(p<0.001)$ were significantly higher in the patient group than the control subjects. GSI $(p<0.001)$ was also prominently higher in the patient group compared to that in the control group. The corresponding scores of SCL-90-R for each item are shown in Table 2. These findings are independent of both the antiepileptic drugs used by the patients and the seizure type.

\section{Discussion}

Although psychiatric disorders are common in PWE, doctors, family members, and patients themselves usually tend to neglect this fact. ${ }^{[2,3,10]}$ The neurologists are generally not interested in psychiatric symptoms of patients, because the main aim of neurologists is to control the seizures of patients. Some quite evident symptoms such as fatigue, tiredness, loss of appetite, although noted, may readily be evaluated as side effects of antiepileptic drugs. Additionally, PWE also may not be able to well define their psychiatric symptoms. Psychiatric symptoms negatively impact the quality of life and make epilepsy difficult to treat. ${ }^{[1]]}$ Gilliam et al. ${ }^{[12]}$ described the Neurological Disorders Depression Inventory for Epilepsy [NDDI-E] to help the rapid detection of major depression in PWE. It has been validated in many languages. ${ }^{[13-16]}$ Although it is a good and rapid test, it only accesses major depression, not the other psychiatric symptoms. Therefore, it is only suitable for PWE and depression.

SCL-90-R is a self-report scale designed to measure the psychiatric symptoms and psychological distress in psychiatric and medical patients. The evaluation of this test can be made after the visit. In the following visit, the patient can discuss their psychiatric symptoms and the effect of antiepileptic drugs with neurologist or with epileptologist, if available. Psychiatry consultation shall be done if necessary. SCL-90-R offers a chance for the detection of psychiatric symptoms.

Former studies have established a higher prevalence of psychiatric symptoms, neurobehavioral problems, and cognitive disturbances in PWE. The first possible explanation to this situation is intrinsic: the similar etiology, pathophysiology, treatment problems, and impact on brain network and intellectual aspect of brain. The second likely explanation is extrinsic: the interaction of patients with other people and family members and the influence of epilepsy on society (marriage, driving, working etc.). ${ }^{[17]}$ The relationship between epilepsy and psychiatric symptoms is quite complex. ${ }^{[2,3]}$ In our study, 14 patients had mental retardation to some degree. PWE are commonly inflicted by mental retardation, and these patients have usually drug-resistant epilepsy. Likewise, 
14 of our patients had mental retardation in this report. They were not eligible as they fail to complete the SCL-90-R.

The mean of individual items and GSI was higher in PWE when compared to the control group. In addition to a likely bidirectional relationship between epilepsy and psychiatric symptoms, our results might be explained as follows:

1. Obsessive-Compulsive Symptom was more commonly encountered, possibly because our entire patient cohort was regularly coming to the outpatient department. Their personality features might be underpinning this disorder. On the other hand, the fear of having a seizure might cause obsessive-compulsive symptoms. Recent data support the hypothesis that temporal lobe epilepsy and obsessive-compulsive symptoms share some pathophysiological components. ${ }^{[18]}$ PWE may also experience some memory disabilities, ${ }^{[19]}$ and these may cause the controlling, doubting, and checking mechanism of obsessive-compulsive symptoms. Some behavioral impairments or organization problems resulting from frontal lobe functional concern in epilepsy may lead to hoarding symptom. ${ }^{[19]}$

2. Anxiety and depression were also more frequent despite the usage of mood regulator drugs by many patients. Anxiety and depression might be explained by the likelihood of having a seizure in any time. This may be because of society and stigma (marriage, work, driving). Unexpected seizures may account for sudden, extreme feelings of fear and embarrassment giving rise to anxiety symptoms of patients.

3. Although patients who had nonepileptic seizures were excluded from the study, the somatization level is high likely because of secondary acquisition from epilepsy.

4. Hostility and interpersonal sensitivity could be explained by the effect of society, treatment of epilepsy, and epilepsy itself.

5. Paranoid and psychotic symptoms could be caused by epilepsy itself and treatment of epilepsy. If it is episodic, the relation with ictus should be evaluated.

6. Phobic anxiety had the lowest psychiatric symptom compared to the other items.

Psychiatric symptoms, not being compared according to seizure types, is the limitation of our study. This issue may be at significant importance due to the possible difference between focal and generalized seizures.

\section{Clinical implications/Future directions}

Although we still do not know whether the psychiatric symptoms are the egg or the chicken, SCL-90-R is an easy test to evaluate psychiatric symptoms. It can be used for PWE to raise awareness of psychiatric symptoms. Once the clinicians become more aware of such symptoms, more accurate approach to the patients will be possible. Studies that contain larger number of patients should be conducted so that the differences of generalized and partial onset epilepsy can be better monitored.

This publication was prepared without any external sources of funding.

\section{Ethics Committee Approval}

Ethics committee approved.

\section{Peer-review}

Externally peer-reviewed.

\section{Conflict of interest}

The authors declare that they have no conflict of interest.

\section{Authorship Contributions}

Concept: G.K., L.I., Y.Ü.; Design: G.K., L.I., Y.Ü.; Supervision: G.K., Ü.B.S.; Materials: G.K., L.I., Y.Ü.; Data collection \&/or processing: G.K., Y.Ü.; Analysis and/or interpretation: G.K., L.İ., Y.Ü.; Literature search: G.K., L.I., Y.Ü.; Writing: G.K., L.I.., Y.Ü.; Critical review: G.K.

\section{References}

1. Sirven Jl. Management of Epilepsy comorbidities. Continuum 2016;22:191-203. [CrossRef]

2. Marsh L, Rao V. Psychiatric complications in patients with epilepsy: a review. Epilepsy Res 2002;49(1):11-33. [CrossRef]

3. Kanner AM. Psychiatric issues in epilepsy: the complex relation of mood, anxiety disorders, and epilepsy. Epilepsy Behav 2009;15(1):83-7. [CrossRef]

4. Mula M. The pharmacological management of psychiatric comorbidities in patients with epilepsy. Pharmacol Res 2016;107:147-53. [CrossRef]

5. Pohlmann-Eden B, Aldenkamp A, Baker GA, Brandt C, Cendes $F$, Coras $R$, et al. The relevance of neuropsychiatric symptoms and cognitive problems in new-onset epilepsy - Current knowledge and understanding. Epilepsy Behav 2015;51:199-209.

6. Derogatis LR. SCL-90 Administration, Scoring and Procedures Manual-I for the Revised Version Baltimore, MD: John Hopkins Univ School of Medicine, 1977.

7. Dag I. Belirti Tarama Listesi (SCL-90-R)'nin üniversite öğrencileri için güvenilirliği ve geçerliği. Turk Psikiyatri Dergisi 1991;2:5-12.

8. Kilic M. Belirti Tarama Listesi (SCL-90-R)'nin Geçerlilik ve Güvenirliği. Turk Psikolojik Danışma ve Rehberlik Dergisi 
1991;1(2):45-52.

9. Kwan P, Arzimanoglou A, Berg AT, Brodie MJ, Allen Hauser W, Mathern $G$, et al. Definition of drug resistant epilepsy: consensus proposal by the ad hoc Task Force of the ILAE Commission on Therapeutic Strategies. Epilepsia 2010;51(6):1069-77. [CrossRef]

10. Gaitatzis A, Trimble MR, Sander JW. The psychiatric comorbidity of epilepsy. Acta Neurol Scand 2004;110(4):207-20. [CrossRef]

11. Kanner AM. Is depression associated with an increased risk of treatment-resistant epilepsy? Research strategies to investigate this question. Epilepsy Behav 2014;38:3-7. [CrossRef]

12. Gilliam FG, Barry JJ, Hermann BP, Meador KJ, Vahle V, Kanner AM. Rapid detection of major depression in epilepsy: a multicentre study. Lancet Neurol 2006;5(5):399-405. [CrossRef]

13. Mula M, ludice A, La Neve A, Mazza M, Bartolini E, De Caro MF, et al. Validation of the Italian version of the Neurological Disorders Depression Inventory for Epilepsy (NDDI-E). Epilepsy Behav 2012;24(3):329-31. [CrossRef]

14. Di Capua D, Garcia-Garcia ME, Reig-Ferrer A, Fuentes-Ferrer M, Toledano R, Gil-Nagel A, et al. Validation of the Spanish ver- sion of the Neurological Disorders Depression Inventory for Epilepsy (NDDI-E). Epilepsy Behav 2012;24(4):493-6. [CrossRef]

15. de Oliveira GN, Kummer A, Salgado JV, Portela EJ, Sousa-Pereira SR, David AS, et al. Brazilian version of the Neurological Disorders Depression Inventory for Epilepsy (NDDI-E). Epilepsy Behav 2010;19(3):328-31. [CrossRef]

16. Zis $P$, Yfanti P, Siatouni A, Tavernarakis A, Gatzonis S. Validation of the Greek version of the Neurological Disorders Depression Inventory for Epilepsy (NDDI-E). Epilepsy Behav 2013;29(3):513-5. [CrossRef]

17. Rektor I, Schachter SC, Arzy S, Baloyannis SJ, Bazil C, Brázdil M, et al. Epilepsy, behavior, and art (Epilepsy, Brain, and Mind, part 1). Epilepsy Behav 2013;28(2):261-82. [CrossRef]

18. Barbieri V, Lo Russo G, Francione S, Scarone S, Gambini O. Association of temporal lobe epilepsy and obsessive-compulsive disorder in a patient successfully treated with right temporal lobectomy. Epilepsy Behav 2005;6(4):617-9. [CrossRef]

19. Kaplan PW. Epilepsy and obsessive-compulsive disorder. Dialogues Clin Neurosci 2010;12(2):241-8. 